\title{
Designing Games To Understand User Preferences Based Player-Centered Design of Indonesian National Heroes
}

\author{
Amirul Muminin ${ }^{1, *}$, Andar Bagus Sriwarno ${ }^{2}$, Intan Rizky Mutiaz ${ }^{3}$ \\ ${ }^{1}$ ITB, Indonesia \\ ${ }^{2}$ ITB, Indonesia \\ ${ }^{3}$ ITB, Indonesia \\ *Corresponding author. Email: amiralmumin96@gmail.com
}

\begin{abstract}
Indonesia in 2021 has 191 heroes, and this research focuses on the 185th hero, Himayatuddin Muhammad Saidi from Southeast Sulawesi, who was crowned on November 7, 2019. These heroes are not yet widely known by Generation Z with a range of births from 1995-2012; they number around 75 million people in Indonesia due to the lack of media to introduce suitable national heroes based on their preferences. There are game media that introduce Indonesian national heroes from the previous literature, but less research has been done on game platforms following Generation-Z preferences. Through this research, we will be studied Generation Z's preferences for four-game genres with the theme of Indonesian national heroes whose research process uses the method Player-Centered Design for the planning stage and the ANOVA (Analysis of Variance) method to determine the most preferred type of game with eight categories as variables containing the impression of Entertainment-Education, Boring-Fun, Spend-Use, Ordinary-Interested, Relax-Fight, Mediocre-Nationalism, No Sacrifice-Sacrifice, and Ordinary-Love Motherland. As a result, the most popular games are the Action of Hero genre with an average score (79.94), Strategy (71.25), RPG (67.09), and Adventure sequence (63.87). There are still 190 other national heroes; from this research, it is hoped that it can be a reference for research on hero-themed game designs and further research for usability testing of the Z-generation.
\end{abstract}

Keywords: Platform Games, Player-Centered Design, National Heroes, Educational Games, Generation-Z.

\section{INTRODUCTION}

With its various islands, Indonesia has historical stories of heroes' struggles representing their regions, containing data on national heroes; currently, there are 191 people [1]. The hero's means as the personification of the values of struggle, the life of the former who sacrificed his life for Indonesia, the awarding of the title of national heroism is a policy of uniting the nation in Indonesia, which has diversity [2]. For the services of the sultanate Himayatuddin Muhammad Saidi who fought his whole life for Buton and Indonesia, he has now been named a national hero, based on a presidential decree, No 120/TK/2019 on November 7, 2019, as a national hero from
Southeast Sulawesi [3]. The 185th Indonesian hero who is still new so that the Z-generation (Gen Z) born in the period 1995-2009 are still not many who recognize the services of the hero Himayatuddin who has twice served as the 20th in 1751-1752 and the 23rd Sultan of Buton, 1760-1763. Himayatuddin is a figure who openly canceled the cooperation agreement with the VOC in 1667, which harmed the Butonese community and for his whole life opposed foreign nations both openly and guerrilla [4]. These heroic values are valuable and need to be introduced to today's young generation because the character of youth is currently experiencing a cultural shift due to modernization and rampant deviant behavior. There is still not an optimal media to introduce heroes to the 
younger generation. Himayatuddin's heroic values and the culture of the Buton fort are currently still dominant in the form of writing and oral traditions [5]. At the same time, the younger generation needs visuals that dominate the learning process, improve memory and communicate concepts [6] so that it is suitable for students and the younger generation; then, the visualization results are used as in-game content. They are conveying the story of heroism through games to suit the younger generation. Game interest is increasing drastically due to trends in the Covid-19 pandemic era. Students have increased the use of smartphones due to online learning during the pandemic, impacting the number of downloads of mobile games in 2020 soaring $75 \%$ [7]. The emergence of massive trends for playing games for the younger generation still lacks in making educational and heroic games in Indonesia. CEO of Agate, several things that make it difficult for local games to develop, including the small number of game companies, the lack of investors for game development, and the lack of talent for game developers [8]. Through the Playstore media, the potential for game distribution will be easier and provide an opportunity to convey the educational value of the story of the national hero Himayatuddin on a national scale.

However, the younger generation tends to prefer entertainment games and tend to spend time. On the other hand, games that focus on education are still less attractive to the younger generation. Therefore, from these problems, the optimal preferences of games such as Adventure, Action, Strategy, and role-playing games (RPG) [9], will be investigated for game platform recommendations about national heroes. Through the Player (Gen Z) centered design method as the dominant preference object by the younger generation and trending game media on Playstore with heroism. From this research, data will be obtained regarding the dominant preference of Gen $\mathrm{Z}$ as the prevalent Player Centered Design, design factors that influence interest in games, and game visualization design so that these results will be interpreted and become gameplay designs that will be applied in the design of the national hero game platform in Indonesia, The use of this method makes it easy to see the journey of the player's experience in making interesting gamification. It makes it easier for researchers to arrange games according to the five stages [10]. This study aims to identify the type of game that suits Gen Z's preferences from the visual perception of game design and introduce Indonesian heroes and heroic values that are appropriate for games using the Player-Centered Design method so that the game design is right on target.

\section{LITERATURE REVIEW}

\subsection{Gen $Z$ and Game Behavior}

Gen $\mathrm{Z}$ is a child who has more interaction with technology, one of which is a smartphone and the generation born in the period from 1995 to 2010 and in Indonesia is dominated by them as much as $27.94 \%$ of the 270 million people, can be defined as many as 75 million population of Indonesia is Gen Z[11]. Gen $\mathrm{Z}$, the children are those with high technological adaptations which are quite adept at playing electronic devices such as computers and gadgets, their tendency to play is no longer in its place, for instance, parks, fields, or places presented to play, but this generation is more dominant in playing digital games [12]. A shift in patterns of play children once on the field is now considered unattractive and replaced with patterns play the game digitally. Gen $\mathrm{Z}$ is also a multitasking internet generation that carries out activities such as social media, exploring the internet through smartphone media in terms of their behavior towards games; namely, they like games that are easy to play have entertaining in-game characters whose information is usually obtained from advertisements on their devices [13]. Through their habits, making gadgets is a medium that has the opportunity to introduce educational games to them.
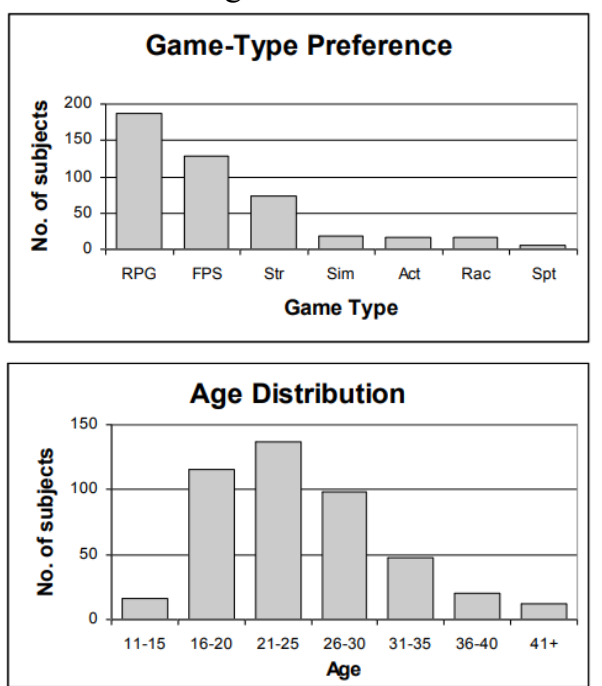

Figure 1 (a) Game Preference statistics; (b) Age distribution of game players.

When viewed in terms of game-playing behavior, players are playing games with the age range of most game users is 21-25 years and 16-20 years[9]. Therefore, the design of this study is aimed at the age 
of 16-24 years which represents the age of the Gen Z. One of the habits of Gen $\mathrm{Z}$ children is to be close to gadget media that gadgets are very closely related to the pattern of children's lives and children are very enthusiastic when involved in the process of developing educational games[9], the media is a means for humans to seek pleasure which has become natural naturally and can also develop cultural values and human life with innovative potential and creativity. By the terms are generally about variance, use the type of game, in terms of preference player games is that there are several types of games that dominant like Role-Playing Game (RPG), first-person shooter (FPS) and Games Strategy (Str). The majority of participants considered themselves to be very experienced, which means they were familiar with the game media, for that the study chose the type of game to study such as Strategy, Action, RPG games and to fit the context of the hero, the researcher added the type of adventure game that represented the story of a heroic adventure. The purpose of these four examples of games is as a reference for the four types of games according to the preferences of generation $\mathrm{z}$ and the visual design of the game platform with a concept about the hero Himayatuddin whose function is to test visual impressions.

\subsection{Heroes As Game Content}

Based on the requirements for the appointment of national heroes, there is a special way, for instance, the administrative requirements proposed from seminars and supporting documents for national heroes like Himayatuddin Muhammad Saidi as the hero proposed from the dissertation of Zuhdi Susanto[5]. Entitled War of Buton VS Dutch Company 1752-1776, commemorating La Karambau's heroism from his dissertation[14].
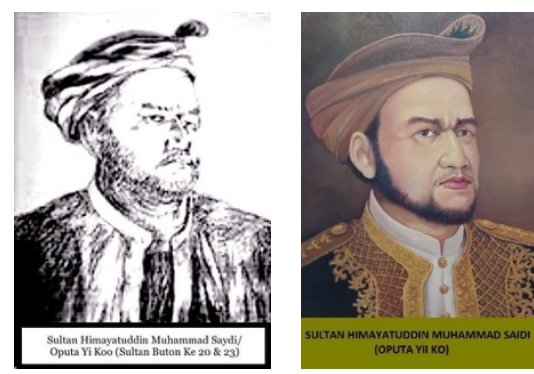

Figure 2 (a) illustration; (b) the book cover of Himayatuddin's hero named Oputa Yi Koo.

Hero Himayatuddin is imaged as Oputa Yi Koo, a king or leader who is a guerrilla in the forest. Judging from the Butonese language, more specifically the
Wolio language, Oputa means lord in this context is the sultanate of Buton, Yi means "at," which means location, and Koo means forest[15]. Himayatuddin is an influential figure in Buton because he has been the sultan two times, the first as the 20th sultan of Buton from 1751-1752 and the 23rd period from 1760-1763. He served in the 23rd sultanate for three years and resigned and went to the forest with his troops. Not because of exile, but it needs to be noted that the struggle Himayatuddin against the Netherlands was never extinguished because in the forest rather mountaintop Siontapina built a fort that was never penetrated by the Dutch troops for a strong defense as well as areas that steep[5], through the story becomes the inspiration of the hero and the story as game content. As the sultan who had fought, he was in the forest and spent his entire life.

\subsection{Value Heroes As Game Content}

The previous research on the development of educational games with national hero content shows that there are advantages value in increasing interest in learning about Indonesian history[16]. The National Archives of Heroic Values, such as an attitude of heroism: willingness to sacrifice, national interest above individual or group interests, sincerity, and love for the homeland[17]. In another way, Appointed as a hero because he has great ideas or thoughts that can support high national development, Have produced great works or increased the nation's dignity, and is A struggle with a wide reach and a national impact[18]. On the other hand, the Degree of heroism given by the president of the Republic of Indonesia for someone who has served, devotion to the nation and the country, and even those who are killed fighting all his life for the sake of Indonesia or result in a work and accomplishments that can be supporting progress and development of the unitary state of Indonesia[18]. Containing data on national heroes, there are currently 191 people, which means that there are many things that can be learned from previous people based on their heroic values. These values need to be introduced to Gen Z, with familiar media such as gadgets, so that the values that are introduced, especially the value of national heroes combined with technology in the form of smartphones through game applications[16], that will teach and entertain as well as provide educational value.

\subsection{Hero-Themed Game Design}

From the results of searching games on the Playstore with the type of games with the theme of national heroism and culture, there are four game design recommendations as follows: 

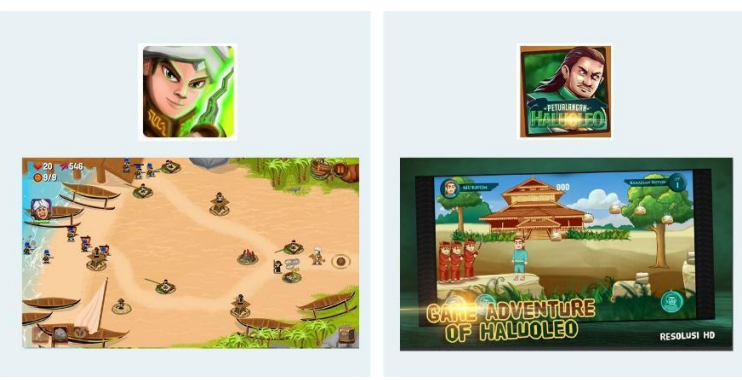

Figure 3 (a) Prince Diponegoro Game; (b) Haluoleo Adventure Game.
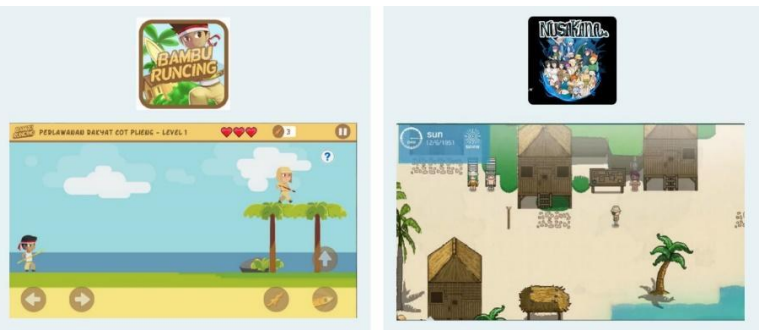

Figure 4 (a) Spiky Bamboo Game; (b) Nasakana.

Based on the four types of games above, representing four types of games will be researched into platform games with heroism. First, the Prince Diponegoro game is a strategy game for the struggle against the colonial forces. Both Haluoleo Adventure games represent the hero's journey and his life. Third, the Bambu Runcing game depicts the story of a heroic struggle against enemy soldiers. Fourth, the Muskana game visualizes the cultural life and character of a region in gameplay.

\section{RESEARCH METHODOLOGY}

The research method uses five stages of PlayerCentered Design consisting of Understanding the player, Understanding the Mission, Understanding Human Motivation, Implementing Game Mechanics, Management, Monitor, and Measure. The first stage focused on understanding insights about the hero's character[9]. The second stage contains the motivation to play games with eight variables such as impressions of Entertainment-Education, Boring-Fun, Spend-Use, Ordinary-Interested, Relax-Fight, MediocreNationalism, No Sacrifice-Sacrifice, and OrdinaryLove Motherland which describes the values of heroism[17]. The third stage, the design stage, is analyzed from four games with the theme of heroes and culture in Indonesia published on the Playstore by following a similar gameplay and User Interface (UI) design. The fourth stage, game design, is implemented in four types of games in mock-up prototypes and game design icons. The fifth stage is measured by the Analysis of Variance (ANOVA) approach method to determine preferences for Z-generation game types. This usage is used to measure the perception of the visual audience in choosing game content[19]. Determination of game preferences was tested from four kinds of games with similar assets, characters, characteristics, UI. The test target questionnaire is addressed to Generation- $Z$ aged 11-25 years with demographics in the Indonesian region with a minimum of 30 respondents.

\section{RESULT AND DISCUSSION}

\subsection{Game Design From Player Centered Design}

This study focuses on the initial design of a herothemed game with the user as the object of research, which will be described as follows:

\subsubsection{Understand the player}

From the questionnaire results, there were 70 respondents; based on gender, there were 31 men and 39 women with an age range of 14-25 years. Based on the insight about the hero's acquaintance, 28 people knew him, and 42 people did not recognize him, it means that Gen $Z$ does not know this hero; therefore, he is suitable as a hero in the game to be introduced.

\subsubsection{Missions and Game Mechanics}

There are four types of games that represent heroism that has been designed with a similar story, game assets, and user interface (UI); The following are the results of the exploration of four-game designs:

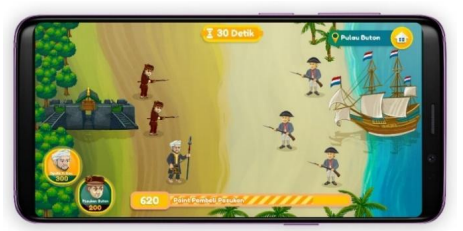

Figure 5 (a) Strategy game design.

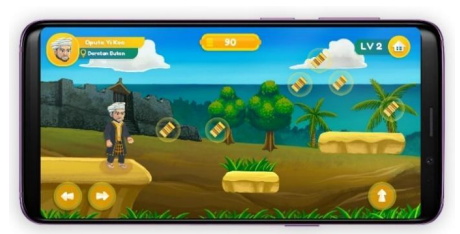

Figure 6 (b) Adventure Games.

First, (a) strategy game that represents a heroic story against the invaders. The main hero character fights against enemy forces, and the key to victory the 
game design focuses on Strategy. The design component contains the main character of the hero, troops as friends, fortifications, enemy forts, enemy troops, timers, coins for buying troops, locations, and homes as settings and backgrounds that describe the atmosphere of the story.

Second, (b) the adventure game depicts a hero who goes on a journey based on the story, and the gameplay tries to collect points and overcome obstacles. The design component contains the main hero display, location, local money, stepping ground as obstacles, UI has jumped, left and right paths, values as points.

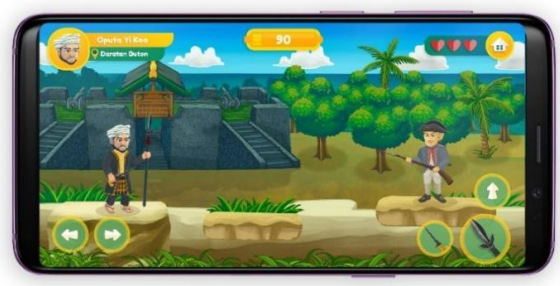

Figure 7 (c) Action game design.

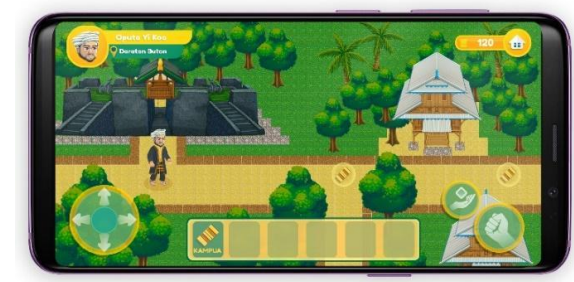

Figure 8 RPG Games.

Third, (c) the action game represents the story of the hero's struggle against the invaders. The main goal of the game is to try to defeat the enemy and continue the struggle. The design component contains the appearance of the main hero, enemy characters, UI in the form of left and right paths, jumps, 1 and 2 attacks, health points, and home as settings.

Fourth, (d) RPG games that visualize the environment, local life, and culture. This game aims to collect items and complete role-playing missions according to the lives of the heroes in the story. The design component contains images of heroes, money as points, bar items, UI in the analog left, right, down, and up, attack and give buttons, and home as settings.

\subsection{Hero Games Preferences and Motivations By Gen Z}

From the results of the VAS questionnaire, the four types of games will be explained sequentially based on the largest to the minor preferences in the form of statistical data containing eight categories that 70 respondents have assessed; for the assessment of choices, there are four variables such as
Entertainment-Education, Boring-Fun, Spend-Use, Ordinary-Interested, and for motivation, there are four variables such as Relax-Fight, Mediocre-Nationalism, No Sacrifice-Sacrifice, and Ordinary-Love Motherland, as follows:

\subsubsection{Preference For Action Games}

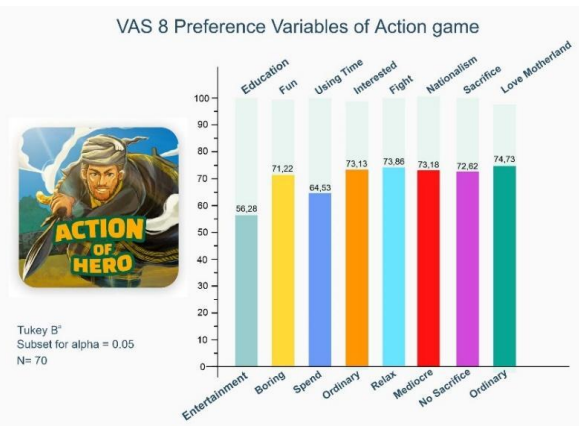

VAS 8 Preference Variables of Strategy game

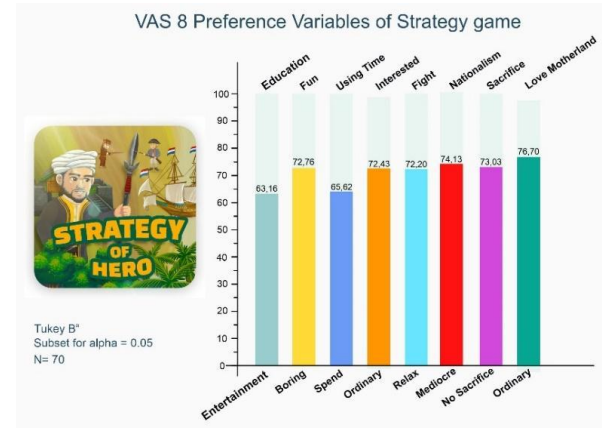

Figure 9.1 (a) The Result of Visual Analogue Scale Rating in Action and (b) Strategy games.

The bar chart in figure (a) illustrates the Visual Analogue Scale that eight variables are Gen $\mathrm{Z}$ preferences for Action games with hero themes. The scale is measured on two opposite sides by analogy with a $0-100$ scale. The largest preference group is Motherland Impression (74.73), followed by Struggle Effect (73.86), Nationalism Impression (73.18), interest (73.13). Then the smallest category is Sacrifice Effect (72.62), Play Effect (71.22), Duration (64.53), Entertainment Impression (56.28). This herothemed action game depicts the impression of love for the homeland with the value of heroic and nationalist action struggles. In addition, the attitude of selfsacrifice gives the appearance of an educational game that is useful for learning time.

\subsubsection{Preference for Strategy Games}

In figure (b), The highest preference is Love 
Motherland Impression with a scale of (76.70), followed by Nationalism Impression (74.13), Sacrifice Effect (73.03), and Play Effect (72.76). The lowest preference is interest (72.43), Struggle Effect (72.20), Impression Duration (65.62), and Entertainment Impression (63.16), respectively. Hero games with war strategy types represent the impression of love for the homeland, give the impression of a character with a nationalist spirit and sacrifice, and give fun with educational games.

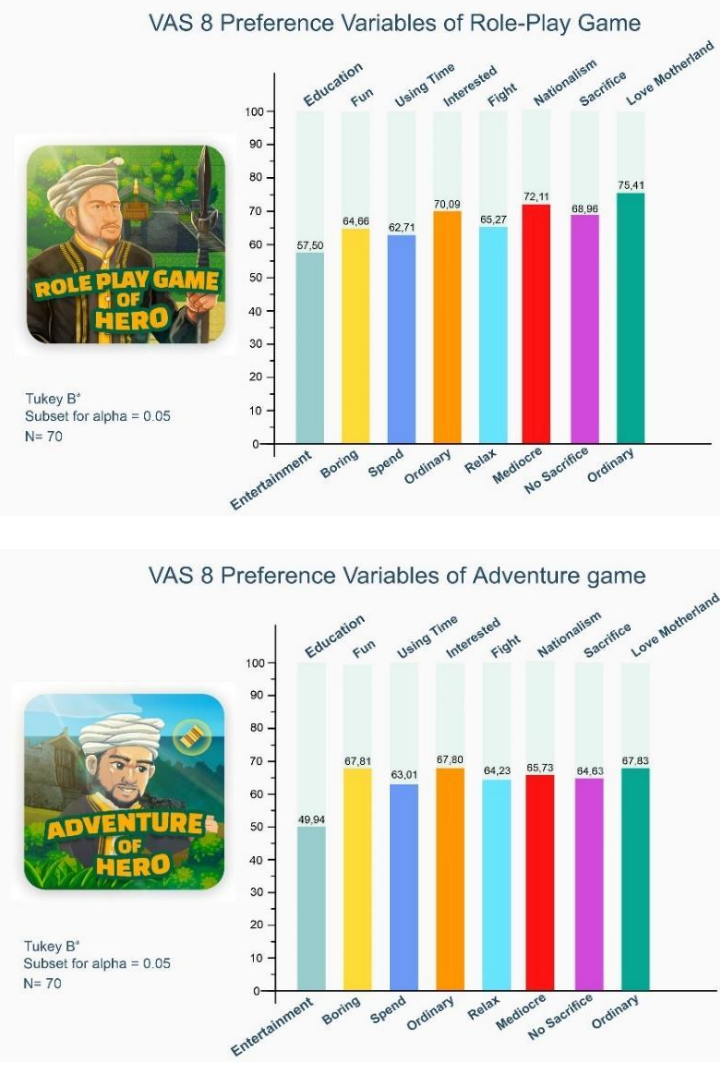

Figure 9.2 (c) Assessment of Visual Analogue Scale on RPG and ; (d) Strategy Game.

In figure (c) describes the In RPG genre, there are the highest preference groups such as the impression of love for the homeland (75.41), the impression of nationalism (72.11), interest in games (70.09), and depicting a self-sacrificing attitude (68.96). In addition, there is an assessment with the lowest group, namely the impression of good struggle in the game (65.27), the appearance of pleasure (64.66), the use of time in playing games (62.71), and the impression of education (57.50). From these data, RPG games generally represent more of an impression of love for the homeland and nationalism, which adds to the image of attractiveness. Still, this game also gives a sufficient impression with an educational image.

\subsubsection{Preferences for Adventure Games}

In figure (d) refers to the game strategy; the data group with the highest preference was found in the impression of Love Motherland (67.83), the impression of pleasure (67.81), the appearance of interest (67.80), and the nationalism (65.73). The other lowest group is the impression of being willing to sacrifice (64.63), the struggle (64.23), the impression of playing games by using the time (63.01) and choosing to play games because of the appearance of entertainment (49.94). This type of adventure game with the theme of heroism represents the impression of love for the homeland with fun and attractiveness and nationalist value for the younger generation. This game tends to be more of an image of entertainment than education.

\subsubsection{Measurement of Hero Game Preference}

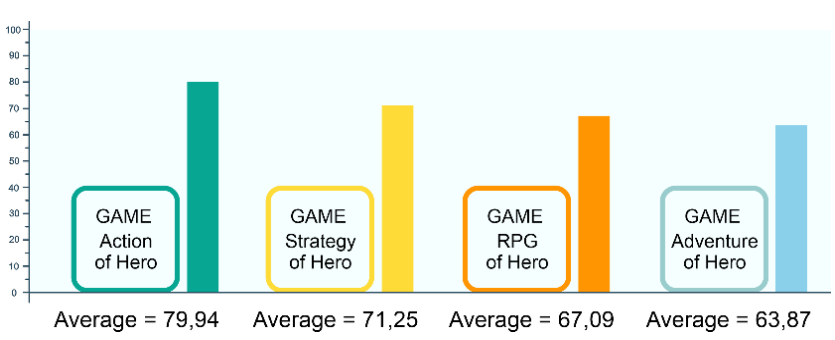

Figure 8 Preference graphics of four kinds of games

From the average results for the four types of games, the best types of hero-themed games can be ranked based on Z-generation ratings in Indonesia. First, Action with an average (79.94), Strategy of Hero (71.25), RPG Game (67.09), and the last order is Adventure of Hero game (63.87). In general, it can be explained that, ideally for games with heroic content, it is made in an action type game because it can represent the struggles of the hero according to Gen $\mathrm{Z}$ preferences. Meanwhile, the type of adventure game is more focused on the element of the impression of fun, making it suitable for games with the theme of heroism with a relaxed atmosphere.

\section{CONCLUSION}

It turns out that in Indonesia, the Hero Himayatudin Muhammad Saidi is still not widely recognized by Gen $Z$. This hero needs to be the main character in the game to be introduced to them from his heroic values such as being willing to sacrifice, for the sake of the national interest above the interests of individuals or groups with sincerity, and love for the homeland.

In general, games with the theme of national 
heroes give a high impression on the elements of fun and educational value and the usefulness of the game to Gen $\mathrm{Z}$ because the hero is the personification of the nation.

From the perspective of game type preferences, Based on the study results, all games with the theme of National Heroes have a dominant impression on the impression of love for the homeland and the impression of being nationalist. Gen $\mathrm{Z}$ in Indonesia dominantly interested in Action of Hero games as the biggest preference with the impression of the value of struggle as an act of heroism with a level of interest and fun that is more as an educational game. Second, Game Strategy represents the impression of struggle, the impression of being willing to sacrifice, and entertainment and fun that is useful as an educational game. Third, RPG represents the impression of an educational game that has more interest and fun and is useful to fill their time. Fourth, Adventure has less impression as an educational game but has the highest value as a game that is entertaining and fun. As an additional suggestion, the hero Himayatuddin Muhammad Saidi is less recognized by Generation Z. Still, if Generation $Z$ recognizes National heroes as game content, it will give a better impression on herothemed games.

From this research, it is hoped that it can be a reference for 190 other National heroes in Indonesia and an overview of game genres that are following the stories and characters of these heroes to be introduced to Gen $\mathrm{Z}$ with media according to their preferences namely smartphone-based educational games.

\section{ACKNOWLEDGMENTS}

Thank you to the Bandung Institute of Technology, LPDP scholarships, and Sangia Studio for helping the smooth running of science, funding and supporting surveys, research content, and hero game design. Special thanks to Zuhdi Susanto as a resource person and researcher who pioneered Himayatuddin Muhammad Saidi as a National Hero from Southeast Sulawesi.

\section{REFERENCES}

[1] Ditektorat2krs, "Prosedur Pengusulan Pahlawan." https://direktoratk2krs.kemsos.go.id/pengu sulangelarpahlawan (accessed Sep. 14, 2021).

[2] V. Marpap, "Kepahlawanan Oputa Yi Koo Sultan Himayatuddin Muhammad Saidi
[ Koja Koja Dengan Prof Susanto Zuhdi ] YouTube."

https://www.youtube.com/watch?v=SWaX UkRp_eA (accessed Sep. 14, 2021).

[3] B. Setpress, "Presiden Jokowi Anugerahkan Gelar Pahlawan Nasional kepada 6 Tokoh," 2019. https://www.presidenri.go.id/siaranpers/presiden-jokowi-anugerahkan-gelarpahlawan-nasional-kepada-6-tokoh/ (accessed Sep. 14, 2021).

[4] Muliadin Iwan, "Pasang-Surut Hubungan Buton - Voc: Studi Masa Sultan Himayatuddin Muhammad Saidi (17511752, Dan 1760-1763)," Universitas Islam Negeri Syarif Hidayatullah, Jakarta, 2014.

[5] Sangia, "Game Pahlawan Oputa Yii Koo, Branding Budaya Lokal Melalui Game Kepahlawanan Sultan Buton,”, Kendari, 2021.

[6] S. Nurannisaa, "Creating graphics for learning and performance : lessons in visual literacy," vol. 1, 2017, pp. 48-59.

[7] Tekno.kompas, "Jumlah Download Game Mobile Pecahkan Rekor Baru Akibat WFH."

https://tekno.kompas.com/read/2020/07/13 /11020057/jumlah-download-gamemobile-pecahkan-rekor-baru-akibat-wfh (accessed Sep. 14, 2021).

[8] Fadli Al Birra, "Indonesia Masih Jadi Pasar, Industri Game Lokal Sulit Maju." https://www.jawapos.com/oto-dantekno/aplikasi/10/07/2019/indonesiamasih-jadi-pasar-industri-game-lokal-sulitmaju/ (accessed Sep. 14, 2021).

[9] P. Sweetser and D. Johnson, "Playercentered game environments: Assessing player opinions, experiences, and issues," Lect. Notes Comput. Sci. (including Subser. Lect. Notes Artif. Intell. Lect. Notes Bioinformatics), vol. 3166, 2004, pp. 321332. DOI: $10.1007 / 978-3-540-28643-$ 1440 .

[10] J. Kumar, Gamification at work: Designing engaging business software, vol. 8013 LNCS, no. PART 2, 2013.

[11] Fuji Pratiwi, "BPS: Gen Z dan Milenial Dominasi Penduduk Indonesia | Republika Online."

https://www.republika.co.id/berita/qna4mf 457/bps-gen-z-dan-milenial-dominasipenduduk-indonesia (accessed Sep. 14, 2021).

[12] B. Fredy, J., \& Saragih, "Fenomena Bermain Generasi dan Hubungannya Dengan Eksistensi Ruang Bermain Terbuka 
Di Lingkungan Perumahan Sederhana," Comtech, vol. 3, no. 1, 2012, pp. 8-14.

[13] ec.europa, "Study on the impact of marketing through social media, online games and mobile applications on children's behaviour | European Commission," 2016. https://ec.europa.eu/info/publications/stud y-impact-marketing-through-social-mediaonline-games-and-mobile-applicationschildrens-behaviour_en (accessed September 14, 2021).

[14] Susanto Zuhdi, Sejarah Buton yang Terabaikan Labu Rope Labu Wana (Edisi Revisi), Revisi. Depok: Wedatama Widya Sastra, 2018.

[15] Indonesia.go.id, "Indonesia.go.id - Tuanku yang Bergerilya di Hutan," 2019. https://indonesia.go.id/kategori/komoditas/ 1385/tuanku-yang-bergerilya-di-hutan (accessed Sep. 14, 2021).

[16] A. Setiawan, R. Kridalukmana, and I. P. Windasari, "Pengembangan Permainan Edukatif Pahlawan Nasional Berbasis Android," J. Teknol. dan Sist. Komput., vol. 3, no. 3, p. 393, 2015, doi: 10.14710/jtsiskom.3.3.2015.393-398.

[17] ArsipNasionalRI, ARSIP Media Kearsipan Nasional Nilai-Nilai Kepahlawanan, Arsip. Jakarta: ANRI, 2014.

[18] Indonesia.go.id, "Indonesia.go.id Prosedur Pengusulan Gelar Pahlawan Nasional."

https://www.indonesia.go.id/layanan/kepe ndudukan/sosial/prosedur-pengusulangelar-pahlawan-nasional (accessed Sep. 14, 2021).

[19] A. Senoprabowo, K. Khamadi, T. Haryadi, and H. D. Yudani, "Persepsi Visual Karakter Warrior Pada Game Online Warcraft, Perfect World, Dan Nusantara Online," Desain Komun. Vis. Manaj. Desain dan Periklanan, vol. 2, no. 02, 2017, pp. 160-181. DOI: 10.25124/demandia.v2i02.933. 